\section{SOCS1 deficiency results in accelerated mammary gland development and rescues lactation in prolactin receptor- deficient mice}

\author{
Geoffrey J. Lindeman, ${ }^{1}$ Sergio Wittlin, ${ }^{1}$ \\ Hania Lada, ${ }^{1}$ Matthew J. Naylor, ${ }^{3}$ \\ Margaret Santamaria, ${ }_{1}^{1}$ Jian-Guo Zhang, ${ }^{1,2}$ \\ Robyn Starr, ${ }^{1,2}$ Douglas J. Hilton,, 2 \\ Warren S. Alexander, ${ }^{1,2}$ Christopher J. Ormandy, ${ }^{3}$ \\ and Jane Visvader ${ }^{1,4}$
}

\begin{abstract}
${ }^{1}$ The Walter and Eliza Hall Institute of Medical Research, Bone Marrow Research Laboratories, and ${ }^{2}$ Cooperative Research Centre for Cellular Growth Factors, PO Royal Melbourne Hospital, VIC 3050, Australia; ${ }^{3}$ Garvan Institute of Medical Research, Darlinghurst, NSW 2010, Australia
\end{abstract}

Prolactin is essential for proliferation and differentiation of the developing mammary gland. We have explored a role for Suppressor of Cytokine Signaling 1 (SOCS1) as a modulator of the prolactin response using mice deficient in SOCS1, which were rescued from neonatal death by deletion of the Interferon gamma $($ IFN $\gamma)$ gene. SOCS1 ${ }^{-/-}$ IFN $\gamma^{-/-}$mice exhibited accelerated lobuloalveolar development in the mammary gland during late pregnancy and precocious lactation. Significantly, the lactogenic defect in prolactin receptor heterozygous females could be rescued by deletion of a single SOCS1 allele. These findings establish a role for SOCS1 as a negative regulator of prolactin signaling and suggest that SOCS1 is required for the prevention of lactation prior to parturition.

Received January 18, 2001; revised version accepted May 5, 2001.

Mammary gland development is governed by the coordinated action of peptide and steroid hormones, such as prolactin, estrogen, and progesterone. Prolactin, a pituitary polypeptide hormone, is a key regulator of mammopoiesis (Vonderhaar 1987; Hennighausen et al. 1997). During pregnancy, prolactin is essential for expansion and differentiation of the lobuloalveolar system. After parturition, prolactin acts in synergy with insulin and glucocorticoids, to induce terminal differentiation and milk production. Binding of prolactin to its cognate receptor (PRLR) triggers dimerization and results in the recruitment and activation of Janus-2 kinase (Jak2). In turn, activated Jak2 phosphorylates the receptor and signal transducer and activator of transcription, Stat5. Activated Stat5 dimers translocate to the nucleus where

[Key Words: Prolactin receptor; SOCS1; mammary gland]

${ }^{4}$ Corresponding author.

E-MAIL visvader@wehi.edu.au; FAX 61-3-9342-8634.

Article and publication are at http://www.genesdev.org/cgi/doi/10.1101/ gad. 880801 . they lead to transcriptional activation of target genes, including those encoding several milk proteins (Watson and Burdon 1996; Hennighausen et al. 1997; Bole-Feysot et al. 1998).

Targeted disruption of genes in the prolactin signaling pathway has highlighted its importance in mammopoiesis and lactogenesis. Prolactin-deficient mice exhibit curtailed ductal branching with arrest of mammary organogenesis at puberty (Horseman et al. 1997). Interestingly, female mice carrying only one intact prolactin receptor allele fail to lactate after their first pregnancy, demonstrating that differentiation is dependent on a threshold level of PRLR (Ormandy et al. 1997; Brisken et al. 1999). Stat5a-null females show a mammary phenotype similar to that of the $\mathrm{PRLR}^{+/-}$females, exhibiting impaired differentiation of lobuloalveolar units and an inability to lactate (Liu et al. 1997; Teglund et al. 1998).

Although the intracellular signaling pathways activated by prolactin are understood relatively well, the mechanisms by which signaling is attenuated are yet to be defined. Negative regulation is likely to involve protein tyrosine phosphatases as well as specific inhibitory molecules such as the suppressor of cytokine signaling (SOCS) proteins. The SOCS family of proteins appear to act in a classical negative feedback loop to regulate signal transduction by a variety of cytokines (Yoshimura 1998; Krebs and Hilton 2000). The eight members (SOCS1-7 and CIS) of this family are characterized structurally by a C-terminal SOCS box, a central SH2 domain, and an N-terminal region of variable length and limited homology (Hilton et al. 1998). Functionally, SOCS proteins interact with cytokine receptors and/or Jak kinases, thereby inhibiting activation of kinases and STAT proteins (Yoshimura 1998; Krebs and Hilton 2000).

SOCS1, one of the founding members of the SOCS family (also termed JAB or SSI-1) (Endo et al. 1997; Naka et al. 1997; Starr et al. 1997), is induced in response to a broad range of cytokines and interacts with the kinase domain of Jak proteins. SOCS1-deficient mice die from a complex neonatal disease prior to weaning, involving fatty degeneration of the liver, macrophage infiltration of several organs, and multiple hematopoietic defects (Naka et al. 1998; Starr et al. 1998). This multiorgan disease can be prevented by neonatal treatment with neutralizing antiinterferon gamma (IFN $\gamma$ ) antibodies and is absent in mice lacking both SOCS1 and IFN $\gamma$ genes, indicating that SOCS1 is a key modulator of IFN $\gamma$ effects (Alexander et al. 1999; Marine et al. 1999a). Thus, additional disruption of the IFN $\gamma$ gene allows the effects of SOCS1-gene deficiency to be studied in adult mice.

The physiological roles of SOCS proteins in mammary development are not known. To investigate the role of SOCS1 in the mammary gland, we have studied mice carrying targeted deletions of the SOCS1 and IFNy genes. These mice exhibited accelerated lobuloalveolar development during pregnancy. Moreover, deletion of a single copy of SOCS1 rescued the lactogenic defect that occurs in $\mathrm{PRLR}^{+/-}$mice (Ormandy et al. 1997). These findings provide evidence that SOCS1 has a biological role in the developing mammary gland, where it acts as a negative regulator of prolactin signaling. Further, the data demonstrate that the absolute levels of both positive and negative modulators of the prolactin pathway 
are critical for directing expansion and differentiation of the mammary gland.

\section{Results}

SOCS1 is expressed in the developing mammary gland

In situ hybridization revealed that SOCS1 RNA is highly expressed in the ductal epithelium and lobuloalveolar units of the developing mammary gland and is apparent, at lower levels, in the surrounding stroma (Fig. 1). SOCS1 RNA appeared to be more abundant in the developing lobuloalveolar units of mammary glands during pregnancy. RT-PCR analysis of mammary tissue from different stages of development confirmed that the level of SOCS1 RNA was higher (>fivefold) in glands from pregnant females relative to those from lactating or involuting glands (data not shown).

\section{Overexpression of SOCS genes inhibits $\beta$-casein} synthesis in mammary epithelial cells

To examine the role of SOCS genes in mammary differentiation, we utilized the mammary epithelial line, SCp2, which displays the essential features of mammary differentiation in the presence of extracellular matrix (ECM) and a lactogenic stimulus (Desprez et al. 1993). Differentiation of these cells is accompanied by the production of milk proteins, such as $\beta$-casein, which we have used here as a molecular marker. Linearized expression vectors containing either SOCS1, SOCS2, SOCS3, or CIS carrying an N-terminal Flag or GFP tag, plus a puromycin resistance cassette, were introduced into SCp2 cells and pools of stable transfectants assayed for their ability to undergo differentiation. For the latter assay, transfectants were plated on ECM in the presence or absence of a lactogenic stimulus.

All four SOCS genes were found to profoundly inhibit $\beta$-casein synthesis by 10 - to 50 -fold, whereas transfectants expressing vector alone were indistinguishable from the parental cells (Fig. 2A). Expression of the Flagtagged SOCS1 and SOCS2 transgenes was readily detectable in SCp2 cells (Fig. 2B) whereas Flag-SOCS3 was undetectable, probably accounting for the weaker inhibition observed. However, expression of a GFP-tagged SOCS3 transgene proved to be more stable in these cells

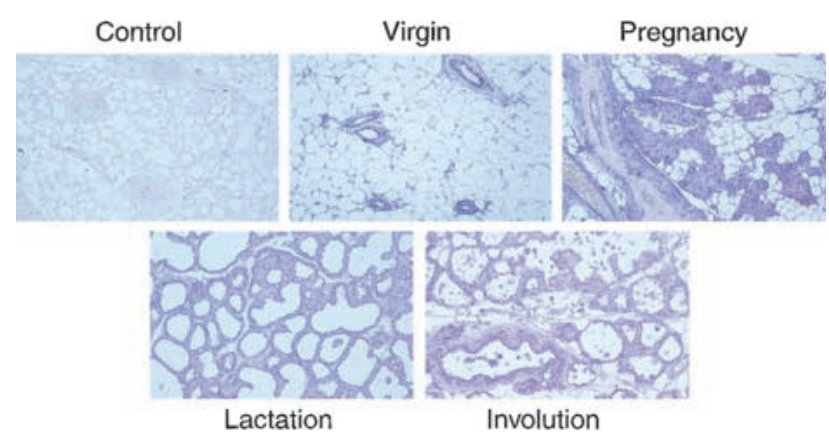

Figure 1. SOCS1 is expressed in ductal epithelium throughout mammopoiesis. A single layer of ductal epithelium expressing SOCS1 transcript is evident in the adult mammary gland. RNA expression was evaluated by in situ hybridization using sense and antisense digoxigenin-labeled riboprobes representing mouse SOCS1 coding sequence. Original magnification, 50x.

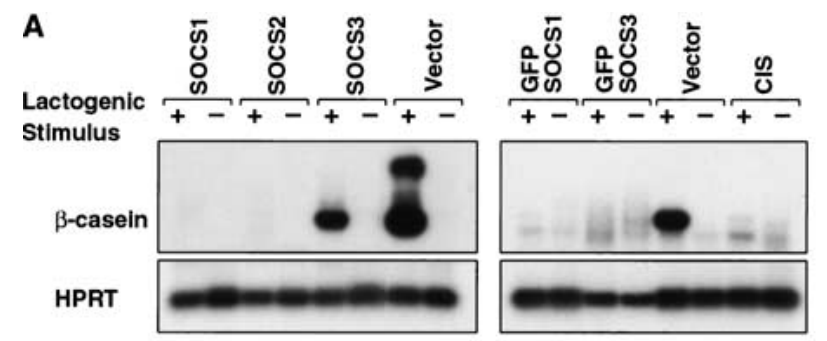

B

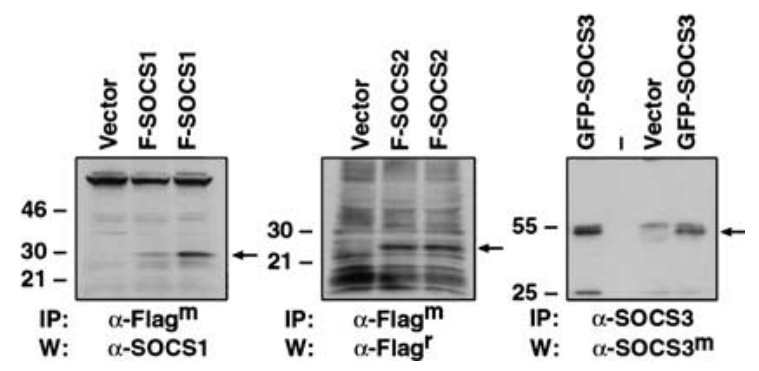

Figure 2. SOCS1-3 and CIS inhibit $\beta$-casein synthesis in SCp2 mammary epithelial cells upon differentiation. (A) RT-PCR analysis was performed using total RNA derived from stably transfected SCp2 pools that were stimulated $(+)$ with prolactin, insulin, and hydrocortisone or unstimulated (-) for $96 \mathrm{~h}$. $\beta$-casein and HPRT were used as markers of differentiation and loading, respectively. At least three independent transfections were performed. (B) Immunoprecipitation and Western blot analysis confirmed expression of SOCS1-3 in SCp2 transfectants. Lysates of cells stably expressing Flag-SOCS1, Flag-SOCS2, GFPSOCS3, or empty vector, from two independent transfections, were subjected to immunoprecipitation using mouse anti-Flag or rabbit anti-SOCS3 antibody as indicated. Western blot analysis was performed with mouse anti-SOCS1, rat anti-Flag, or mouse anti-SOCS3 antibodies. Arrows indicate relevant SOCS proteins.

(Fig. 2B) and, accordingly, was more effective in blocking $\beta$-casein mRNA synthesis (Fig. 2A). Thus, SOCS1-3 and CIS all can act as negative regulators of the endogenous prolactin signaling pathway in SCp2 cells.

\section{SOCS1 deficiency accelerates lobuloalveolar development}

Since targeted deletion of the IFNy gene rescues $\mathrm{SOCS1}^{-/-}$mice from death at $2 \mathrm{wk}$ of age (Alexander et al. 1999; Marine et al. 1999b), these double knockout mice could be used to study the effect of SOCS1 deficiency on mammopoiesis by comparison with mice lacking IFN $\gamma$ alone. SOCS $1^{-/-} / \mathrm{IFN}^{-1-}$ mice were crossed to generate females for developmental analysis whereas $\mathrm{SOCS}^{+/+} / \mathrm{IFN} \gamma^{-/-}$mice were bred to generate control IFN $\gamma^{-/-}$females. Between 4-8 age-matched female mice of each genotype were analyzed at different stages. Importantly, loss of IFN $\gamma$ had no discernible effect on mammary development as these mice appeared identical to wild-type mice at all stages of development. No overt differences were found between mammary glands from $\mathrm{SOCS}^{-/-} / \mathrm{IFN} \gamma^{-/-}$females versus those from IFN $\gamma^{-/-}$or wild-type mice at 4, 6, 9, 12, 15, and $18 \mathrm{wk}$ (data not shown).

SOCS1 deficiency led to increased development of the lobuloalveolar units during pregnancy, as revealed by wholemount analysis and histological sectioning. There 
was a markedly higher density of lobuloalveolar units in mammary glands from SOCS1 ${ }^{-1-} / \mathrm{IFN}^{-1-}$ mice, apparent from day 16 of pregnancy, relative to those from control mice (Fig. 3A,B). By day 18 of pregnancy, these units had substantially penetrated the mammary fat pad and displayed dilated lumens. Although development was more advanced at day 1 of lactation in the double knockout females, there was no difference by day 5 . The rate of proliferation appeared to be similar for SOCS1 $1^{-/-} \mathrm{IFN} \gamma^{-/-}$ and IFN $\gamma^{-1-}$ mammary epithelium, based on BrdU staining at days 13 and 16 of pregnancy (data not shown).

\section{Increased milk production in the absence of SOCS1}

The dilated acini evident in mammary glands from day 18 pregnant and day 1 lactating SOCS $1^{-/-} / \mathrm{IFN}^{-/-}$mice suggested increased production and secretion of milk. Western analysis of whole-cell extracts from double knockout and age-matched control mice using antimouse milk antisera confirmed that there were significantly higher levels of milk proteins in the mammary gland in the absence of SOCS1. Fig. 4A shows milk protein expression for three sets of mice at day 18 of pregnancy in which WAP (14 kD) and $\alpha$-casein $(46 \mathrm{kD})$ are markedly up-regulated, as well as $\beta$-casein (30 kD). Milk protein levels were elevated from day 16 of pregnancy through to day 1 of lactation in SOCS1 $1^{-/-} / \mathrm{IFN}^{-/-}$mammary glands relative to those from control mice, with the maximal difference occurring at day 18 of pregnancy (Fig. 4B).

Since Stat5 is an important transcriptional effector in the prolactin pathway (Liu et al. 1997; Teglund et al. 1998) and is known to directly regulate expression of milk protein genes, we examined whether phosphoryla-

A

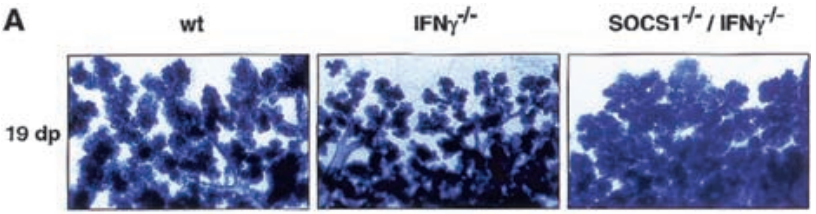

B

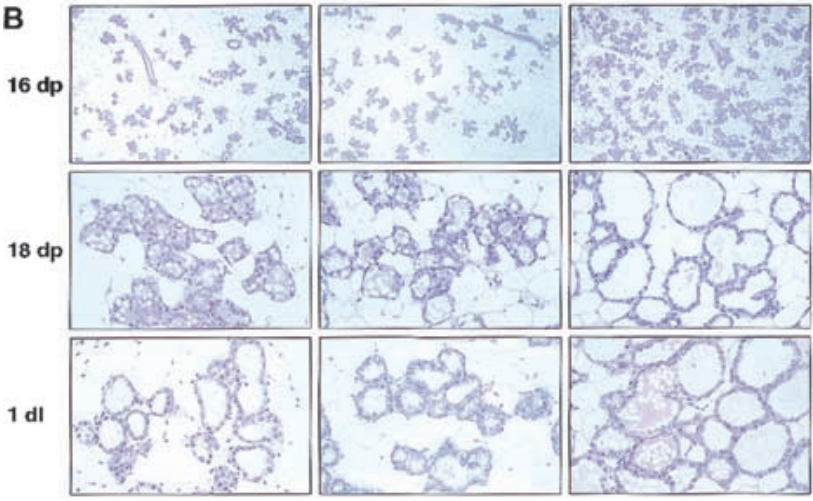

Figure 3. Lobuloalveolar development is accelerated in the SOCS1-deficient mammary gland during pregnancy. (A) Wholemount analysis and $(B)$ histological sections of $\mathrm{SOCS1}^{-/-}$ IFN $\gamma^{-/-}$mammary tissue showed precocious development of lobuloalveolar units, apparent at day 16 of pregnancy through to day 1 of lactation, when compared to control mice (wild type and IFN $\gamma^{-1-}$. Original magnification: $16 \mathrm{dp}, 20 \times ; 18 \mathrm{dp}$ and $1 \mathrm{dl}$, $100 \times$. tion of Stat5 was elevated in $\mathrm{SOCS}^{-/-} / \mathrm{IFN} \gamma^{-/-}$mice. Higher levels of phosphorylated Stat5 were found in mammary glands at day 1 of lactation relative to controls (Fig. 4C), although there was no apparent difference during pregnancy. Furthermore, there was no change in Stat5 DNA-binding activity during pregnancy (data not shown). Interestingly, substantially less MAP kinase activity (phospho-Erk1 and phospho-Erk2) was found in SOCS1 $1^{-/-} / \mathrm{IFN}^{-/-}$mammary glands at day 18 of pregnancy and day 1 of lactation, relative to control mammary tissue (Fig. 4D). The level of total Erk1/2 remained the same (Fig. 4D), indicating that MAP kinase activity was reduced. It is not known whether SOCS1 directly influences MAP kinase activity but the diminished levels most likely reflect the differentiated state of the epithelium.

\section{Deletion of one SOCS1 allele rescues the lactogenic defect exhibited by prolactin receptor heterozygous females}

Young PRLR ${ }^{+/}$females fail to lactate after their first pregnancy because of impaired lactogenesis but can lactate after subsequent pregnancies (Ormandy et al. 1997). Thus a single functional allele of $P R L R$ is insufficient to drive the final rounds of epithelial differentiation and lactogenesis. This mammary defect varies in its penetrance, dependent on strain background (C.J. Ormandy, unpubl.).

To determine whether the lactogenic defect in PRLR mice was epithelial specific, we used epithelial explants from $\mathrm{PRLR}^{+/-}$or $\mathrm{PRLR}^{+/+}$mice transplanted into the cleared mammary fat pads of $\operatorname{Rag} 1^{-/-}$recipients. Reconstitution of wild-type stroma with $\mathrm{PRLR}^{+/-}$epithelium failed to rescue lobuloalveolar development during pregnancy, providing direct evidence that the defect lies in the epithelium (Fig. 5A). Moreover, recombination experiments using PRLR ${ }^{-/-}$epithelium or stroma revealed that PRLR is required in mammary epithelium but not in stroma for normal development (M.J. Naylor and C.J. Ormandy, data not shown).

To examine whether a reduction in the level of SOCS1 might rescue signal transduction along the prolactin pathway, we generated females that were heterozygous for both PRLR and SOCS1 and compared these to either $\mathrm{SOCS}^{+/-}$, PRLR ${ }^{+/}$, or wild-type littermates. We found that six out of six double heterozygous females were capable of lactation after their first pregnancy, whereas four out of six PRLR ${ }^{+/-}$females exhibited reduced lactation. Wholemount and histological analysis of glands from the rescued mice revealed normal morphology of the lobuloalveolar structures in $\mathrm{PRLR}^{+/-} / \mathrm{SOCS}^{+/-}$mice at day 2 postpartum but dramatically reduced development in four PRLR ${ }^{+/}$females (Fig. 5B,C). The rescue of lobuloalveolar development also was achieved in $\mathrm{PRLR}^{+/-}$/ SOCS1 $1^{+/-}$mice on a different SOCS1 (129Sv) background. Expression of WAP and $\beta$-casein milk protein genes in $\mathrm{PRLR}^{+/-} / \mathrm{SOCS}^{+/-}$mammary glands was restored to that seen in wild-type glands, in contrast to the lower levels evident in PRLR ${ }^{+/-}$mice (Fig. 5D).

\section{Discussion}

Pathways that direct proliferation and differentiation must be tightly controlled to ensure the appropriate intensity and duration of response. The molecular mecha- 

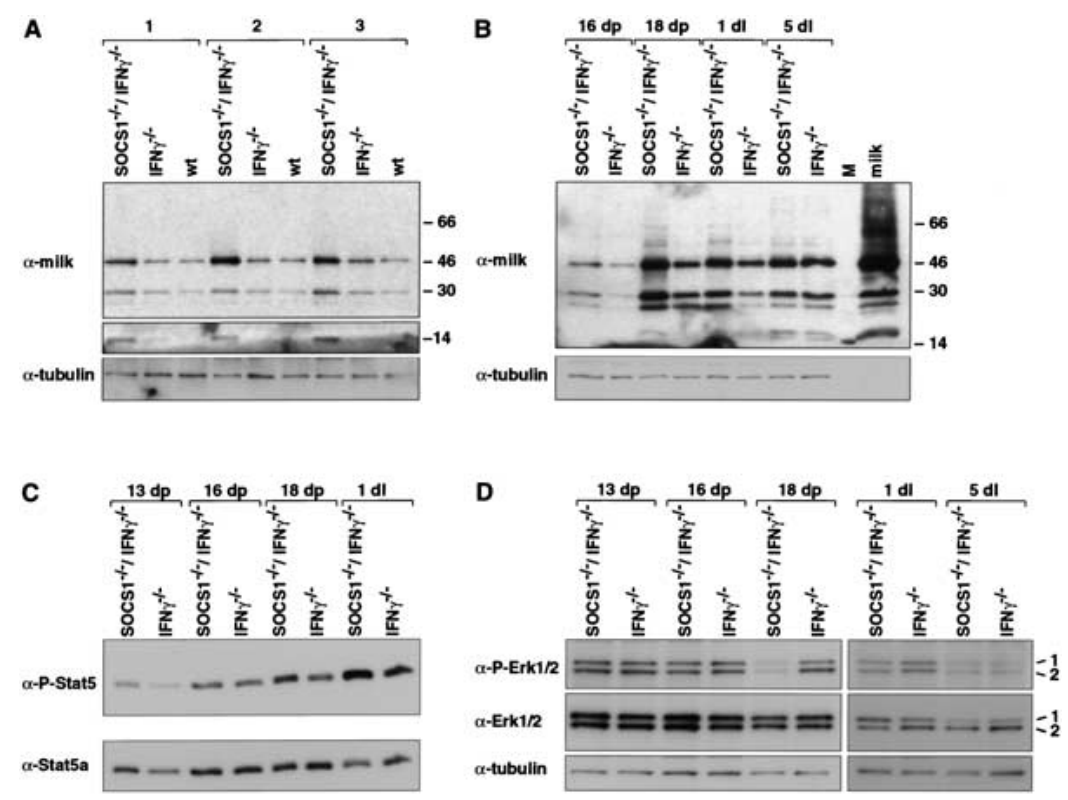

Figure 4. Analysis of expression of milk protein, Stat5, and MAP kinase in SOCS1/IFN $\gamma$-deficient mammary glands. (A) Increased milk production in the absence of SOCS1. Whole-cell extracts from three age-matched sets of SOCS1 ${ }^{-1-}$ IFN $\gamma^{-/-}$, IFN $\gamma^{-/-}$, and wild-type mammary tissue at day 18 of pregnancy were analyzed by Western blot using anti-mouse milk antisera. (B) Time course of milk protein expression in the developing SOCS1 $1^{-/-} / \mathrm{IFN} \gamma^{-/-}$mammary gland. Western blot analysis revealed elevated milk protein expression in $\mathrm{SOCS1} 1^{-/-} / \mathrm{IFN} \gamma^{-/-}$mice from day 16 of pregnancy through to day 1 of lactation. $\mathrm{M}$, marker lane. $(C)$ Increased levels of phosphorylated Stat5 in lactating SOCS1 ${ }^{-/-} / \mathrm{IFN}^{-/-}$mammary glands. Whole-cell extracts from different stages were fractionated by extended electrophoresis (5\% PAGE) and blotted with anti-phospho-Stat5 or anti-Stat5a antisera. Fractionation experiments indicated that the majority of phospho-Stat 5 corresponds to Stat5a. $(D)$ Decrease in phosphorylated MAP kinase in SOCS1 $1^{-1-}$ IFN $\gamma^{-/-}$mammary glands. Western blot analysis of whole-cell extracts using antiphospho-Erk 1 and 2 or anti-Erk 1 and 2 antisera. Protein loading was confirmed using anti- $\alpha$-tubulin.

nisms that attenuate signaling by prolactin, a hormone essential for breast epithelial proliferation and differentiation, are poorly defined. Receptor internalization, tyrosine phosphatase inactivation and/or specific suppressors of cytokine signaling (SOCS) are utilized by a variety of signaling pathways. The protein tyrosine phosphatase SHP-2 has been implicated in PRLR-mediated signaling but the data indicates that it is acting as a positive rather than negative regulator (Ali et al. 1996). In this paper, we provide evidence that SOCS1 is a negative regulator of prolactin signaling in vivo using two different sets of targeted mice. The precocious lobuloalveolar development that occurs in SOCS1/IFN $\gamma$-deficient females but not those lacking IFN $\gamma$ alone, is compatible with SOCS1 acting as an inhibitor. PRLR ${ }^{+/}$mice exhibit a specific defect in mammary differentiation. Whilst the architecture of the lobuloalveolar units is normal in these mice, the alveoli fail to dilate with milk, because of lack of terminal differentiation. Rescue of the lactogenic defect in PRLR ${ }^{+/-}$females by removal of a single SOCS1 allele demonstrates that SOCS1 is indeed affecting prolactin signal transduction. The threshold level of PRLR required for terminal epithelial differentiation and lactogenesis is presumably restored by reducing the level of a negative regulator of this pathway.
Expansion and maturation of the lobuloalveolar system are achieved earlier in the absence of SOCS1. The morphological effects of SOCS1 deficiency are first seen around day 16 of pregnancy but are no longer evident by day 5 of lactation. Because the lactogenic defect in $\mathrm{PRLR}^{+/-}$ mice is epithelial-specific (Fig. 5A), rescue of this phenotype by diminution of SOCS1 indicates that SOCS1 is acting cell autonomously within the epithelium. This is consistent with expression of SOCS1 in the ductal epithelium and its prolactin inducibility in breast epithelial cells (Pezet et al. 1999; data not shown). It is plausible that SOCS1 deficiency may have additional effects via the stroma, which could be addressed by reciprocal transplantation studies. It is notable that serum prolactin levels in adult $\mathrm{SOCS}^{-/-} / \mathrm{IFN}^{-/-}$, IFN $\gamma^{-/-}$, and wild-type mice were within the normal range (data not shown). This finding further supports a direct role for SOCS1 in the mammary gland.

SOCS1 may play a negative regulatory role in the induction of lactation after parturition. Lactation is a complex process that is determined in part by a postpartum decrease in progesterone and increase in serum prolactin levels (Wilde and Hurley 1996; Neville and Daniel 1998). The inhibition of lactation that is normally relieved at parturition is lost early in the $\mathrm{SOCS1}^{-1}$ -/IFN $\gamma^{-/}$mice, resulting in precocious lactation. Remarkably, there does not appear to be functional redundancy between different SOCS proteins at this stage of mammary development, despite coexpression of at least five members of this family during pregnancy and lactation (data not shown). Interestingly, SOCS2-null mice have no apparent mammary perturbation at lactation (C. Greenhalgh, data not shown), despite the phenotype indicating that it is an important regulator of the growth hormone/ IGF-1 pathway (Metcalf et al. 2000). Thus, SOCS1 but not SOCS2 appears to have an essential negative regulatory role in the prolactin pathway.

SOCS proteins act as potent inhibitors of prolactin signaling in vitro but there appears to be little specificity amongst the different family members in these overexpression systems. We have shown here that SOCS1-3 and CIS inhibited $\beta$-casein synthesis when introduced into a differentiative mammary epithelial cell line. Other groups have previously reported that SOCS1, SOCS3, and SOCS2 partially, but not CIS can inhibit prolactin signaling in transiently transfected $293 \mathrm{~T}$ cells (Helman et al. 1998; Pezet et al. 1999; Tomic et al. 1999). These seemingly discrepant data are likely to reflect different cell types and the use of an endogenous, versus transiently expressed, prolactin receptor. In summary, these in vitro studies have not proven conclusive in addressing the biological specificity of the SOCS family members within the mammary gland. Transgenic mice expressing CIS1 under the control of the $\beta$-actin promoter fail to lactate as a result of defective mammary differentiation (Matsumoto et al. 1999). This suggests 
A
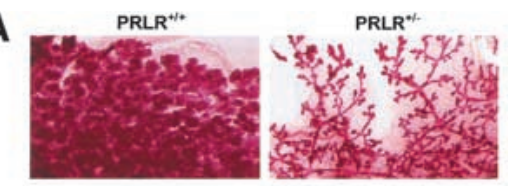

B
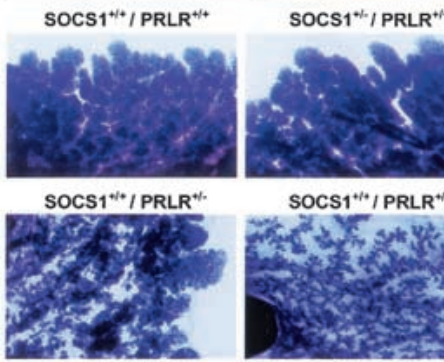

SOCS1*/PRLR ${ }^{\text {t. }}$
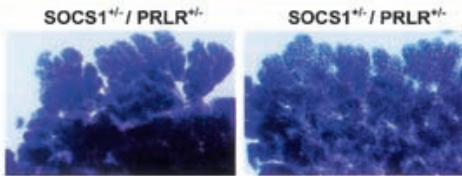

SOCS $1^{* /} /$ PRLR $^{* / *}$

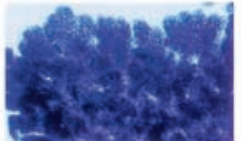

D

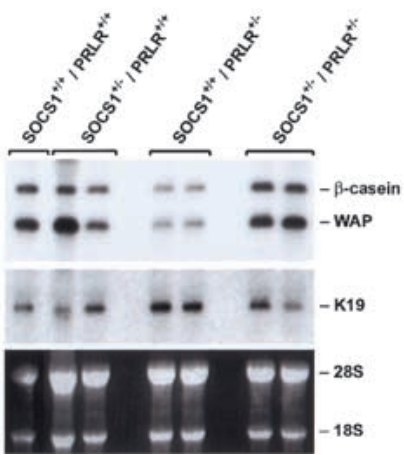

Figure 5. Rescue of lactation in $\mathrm{PRLR}^{+/-}$mice by deletion of a single SOCS1 allele. (A) PRLR is required by the epithelium to direct lobuloalveolar development. Mammary epithelium from $\mathrm{PRLR}^{+/+}$and $\mathrm{PRLR}^{+/-}$mice was transplanted into cleared fourth fat pads of prepubertal Rag $1^{-/-}$females, which were then taken through pregnancy. Wholemounts of $1 \mathrm{~d}$ postpartum mammary glands are shown. $(B)$ Wholemount analysis of mammary glands at day 2 of lactation from SOCS1 $\times$ PRLR mice (genotype indicated). Mice were mated at $7 \mathrm{wk}$ of age. Six mice of each genotype were analyzed. (C) Histological analysis of mammary glands (day 2 postpartum). Original magnification, 50×. $(D)$ Northern analysis (10 $\mu \mathrm{g}$ of total RNA) of milk gene expression. Filters were hybridized sequentially with probes representing Keratin 19 (K19), $\beta$-casein, and WAP.

that CIS can alter mammopoiesis when overexpressed, but as CIS ${ }^{-1-}$ mice have no obvious phenotype (Marine et al. 1999b), it may not reflect a physiologically important action of this regulator.

The signal transduction pathways regulated by SOCS1 in the mammary gland remain to be defined. SOCS1 can regulate cytokine signal transduction through direct inhibition of the Jak family of protein tyrosine kinases (Endo et al. 1997; Naka et al. 1997) and Stat5 is a direct target of Jak2. Consistent with these findings, an increase in phosphorylated Stat5 was observed at day 1 of lactation in SOCS1 ${ }^{-/-} / \mathrm{IFN}^{-/-}$glands relative to control mammary tissue. However, no increase was apparent during pregnancy when the phenotype was first manifest. These results suggest that the Stat5-response is pro- longed but not amplified in the mammary glands of SOCS $1^{-/-} / \mathrm{IFN}^{-/-}$mice, as has been observed for Stat 1 in hepatocytes from these mice (R. Starr, unpubl.). Alternatively, another SOCS1-regulated pathway may also contribute to prolactin signaling. The observation that Stat5a-null mice are capable of milk protein synthesis invokes additional pathways in signaling by prolactin. The identification of such pathways should provide insight into the molecular basis of SOCS1 inhibition in the mammary gland.

\section{Materials and methods}

In situ hybridization

Full-length mouse SOCS1 cDNA (Starr et al. 1997) was cloned into Bluescript SKII (Stratagene). Antisense and sense riboprobes were generated using T3 or T7 RNA polymerase (Promega) with digoxigenin-UTP (Roche). Standard in situ hybridizations were performed as described (Wilkinson 1992).

SCp2 cell differentiation assay

SCp2 mammary epithelial cells (Desprez et al. 1993) were passaged in DMEM-F12 media containing 10\% FCS, and $5 \mu \mathrm{g} / \mathrm{mL}$ insulin (Sigma). Full-length cDNAs corresponding to SOCS1-3 (Hilton et al. 1998) and CIS (Yasukawa et al. 1999), all carrying an N-terminal FLAG- or GFPepitope tag, were cloned into the pEF1 $\alpha$-puro mammalian expression vector (Huang et al. 1997). Protein expression was confirmed by transient transfection of $293 \mathrm{~T}$ cells. Linearized expression vectors $(10 \mu \mathrm{g})$ were introduced into SCp2 cells using Superfect (QIAGEN) and selected in puromycin for $10 \mathrm{~d}$. Pools of stable transfectants were then used in the differentiation assay, essentially as described (Desprez et al. 1993).

RNA analysis and RT-PCR

Total RNA was isolated from SCp2 cells on ECM using RNAzol (TelTest); cDNA synthesis and PCR were performed as described (Weiss et al. 1994), using primers for $\beta$-casein and HPRT (Weiss et al. 1994). Sequences of the $\beta$-casein primers were: forward 5 -ATGAAGGTCTTCA TCCTCGCCTGCC-3' , reverse 5' -GCTGGACCAGAGACTGAGGAAG GTGC-3'. Northern analysis of total RNA was performed as described (Weiss et al. 1994).

Immunoprecipitation and Western analysis

Whole-cell lysates were generated from stably transfected SCp2 pools by lysing cells in KALB lysis buffer containing protease inhibitors /Complete Cocktail, Roche). Proteins were immunoprecipitated with anti-Flag M2 (Sigma) or rabbit antiserum raised against full-length SOCS3, and protein G Sepharose (Pharmacia), and separated by SDS-PAGE (Novex). After transfer, filters were blocked and incubated with mouse antiSOCS1, rat anti-Flag, or mouse anti-SOCS3 ( $\mathrm{N}$ terminus) monoclonal antibodies. Antibody binding was visualized with peroxidase-conjugated antimouse (Amersham) or anti-rat antibody (Jackson Immunoresearch Laboratories) using the ECL system (Amersham).

Mouse mammary lysates were prepared in $150 \mathrm{mM} \mathrm{NaCl}, 5 \mathrm{mM}$ EDTA, 50 mM Tris-Cl (pH 7.5), 0.1\% NP-40, 0.1\% deoxycholate containing protease inhibitors. After protein fractionation and transfer, filters were blocked with $50 \mathrm{mM}$ sodium phosphate (pH 7.0), $50 \mathrm{mM} \mathrm{NaCl}$, $0.05 \%$ Tween 20 , and incubated with one of the following primary antibodies: rabbit polyclonal antiserum raised against mouse milk-specific proteins (Accurate Chemical \& Scientific Corporation), anti-phosphoStat5a/b or anti-Stat5a monoclonal antibody (Upstate Biotech), antiERK1/2 (p44/42 MAPK) or anti-phospho ERK1/2 monoclonal antibody (New England Biolabs), anti- $\alpha$-tubulin monoclonal antibody (Sigma). For milk protein detection, $400 \mathrm{ng}$ of protein was loaded per lane, while other blots were performed using $20 \mu \mathrm{g}$ protein per lane.

Derivation and maintenance of mice

The derivation of SOCS1-/- and IFN $\gamma^{-/-}$mice has been described previously (Alexander et al. 1999). SOCS1 ${ }^{-/-} / \mathrm{IFN} \gamma^{-/-}$mice were originally maintained on a hybrid 129/Sv and C57BL/6 (SVB6) genetic background, while IFN $\gamma^{-/-}$mice were on an inbred C57BL/6 background. SOCS1 ${ }^{-1-}$, $\mathrm{IFN} \gamma^{-/-}$, $\mathrm{SOCS}^{+/+} / \mathrm{IFN}^{-/-}$and $\mathrm{SOCS}^{+/+} / \mathrm{IFN} \gamma^{+/+}$mice were generated by crosses and then propagated as intercrosses. PRLR ${ }^{+/-}$(129Ola/ 
129SvPas background) mice were mated with SVB6 or 129Sv SOCS1+/animals to generate pups heterozygous for both alleles on two different backgrounds. Mice were genotyped by Southern blot analysis (SOCS1) and PCR of genomic tail DNA (PRLR) (Ormandy et al. 1997; Alexander et al. 1999). Mice were routinely housed in conventional facilities at WEHI.

Adult female mice were mated and pregnancy scored by the observation of a vaginal plug and confirmed by examination of embryos when mammary glands were collected. Following parturition, litters with at least six pups were maintained. Pups were removed after 7-10 d to initiate involution.

Histology, mammary gland wholemounts, and transplants For histological examination, tissues were fixed in $10 \%(\mathrm{v} / \mathrm{v})$ formalin in phosphate-buffered saline (PBS), embedded in paraffin and sections (1.5 $\mu \mathrm{m})$ prepared and stained with hematoxylin and eosin. For wholemount examination, tissues were fixed in Carnoy's solution and stained with hematoxylin or carmine alum. Epithelial transplants into cleared mammary fat pads were carried out as described (Brisken et al. 1999).

\section{Acknowledgments}

We are grateful to H. Davey and A. Craven for serum prolactin assays. We also thank S. Mihajlovic for histology, D. Postma for assistance in the animal facilities, M. Bissell for SCp2 cells, and A. Parlow for prolactin. This work was supported by the Victorian Breast Cancer Research Consortium, Australia.

The publication costs of this article were defrayed in part by payment of page charges. This article must therefore be hereby marked "advertisement" in accordance with 18 USC section 1734 solely to indicate this fact.

\section{References}

Alexander, W.S., Starr, R., Fenner, J.E., Scott, C.L., Handman, E., Sprigg, N.S., Corbin, J.E., Cornish, A.L., Darwiche, R., Owczarek, C.M., et al. 1999. SOCS1 is a critical inhibitor of interferon gamma signaling and prevents the potentially fatal neonatal actions of this cytokine. Cell 98: $597-608$

Ali, S., Chen, Z., Lebrun, J.J., Vogel, W., Kharitonenkov, A., Kelly, P.A., and Ullrich, A. 1996. PTP1D is a positive regulator of the prolactin signal leading to beta-casein promoter activation. EMBO J. 15: 135-142.

Bole-Feysot, C., Goffin, V., Edery, M., Binart, N., and Kelly, P.A. 1998 Prolactin (PRL) and its receptor: Actions, signal transduction pathways and phenotypes observed in PRL receptor knockout mice. Endocr. Rev. 19: 225-268.

Brisken, C., Kaur, S., Chavarria, T.E., Binart, N., Sutherland, R.L., Weinberg, R.A., Kelly, P.A., and Ormandy, C.J. 1999. Prolactin controls mammary gland development via direct and indirect mechanisms. Dev. Biol. 210: 96-106.

Desprez, P.-Y., Roskelley, C., Campisi, J., and Bissell, M.J. 1993. Isolation of functional cell lines from a mouse mammary epithelial cell strain: The importance of basement membrane and cell-cell interaction. Mol. Cell. Diff. 1: 99-110.

Endo, T.A., Masuhara, M., Yokouchi, M., Suzuki, R., Sakamoto, H., Mitsui, K., Matsumoto, A., Tanimura, S., Ohtsubo, M., Misawa, H., et al. 1997. A new protein containing an SH2 domain that inhibits JAK kinases. Nature 387: 921-924.

Helman, D., Sandowski, Y., Cohen, Y., Matsumoto, A., Yoshimura, A., Merchav, S., and Gertler, A. 1998. Cytokine-inducible SH2 protein (CIS3) and JAK2 binding protein (JAB) abolish prolactin receptor-mediated STAT5 signaling. FEBS Lett. 441: 287-291.

Hennighausen, L., Robinson, G.W., Wagner, K.U., and Liu, W. 1997. Prolactin signaling in mammary gland development. J. Biol. Chem. 272: 7567-7569.

Hilton, D.J., Richardson, R.T., Alexander, W.S., Viney, E.M., Wilson, T.A., Sprigg, N.S., Starr, R., Nicholson, S.E., Metcalf, D., and Nicola, N.A. 1998. Twenty proteins containing a C-terminal SOCS box form five structural classes. Proc. Natl. Acad. Sci. 95: 114-119.

Horseman, N.D., Zhao, W., Montecino-Rodriguez, E., Tanaka, M., Nakashima, K., Engle, S.J., Smith, F., Markoff, E., and Dorshkind, K. 1997. Defective mammopoiesis, but normal hematopoiesis, in mice with a targeted disruption of the prolactin gene. EMBO J. 16: 69266935.
Huang, D.C., Cory, S., and Strasser, A. 1997. Bcl-2, Bcl-XL and adenovirus protein E1B19kD are functionally equivalent in their ability to inhibit cell death. Oncogene 14: 405-414.

Krebs, D.L. and Hilton, D.J. 2000. SOCS: Physiological suppressors of cytokine signaling. J. Cell Sci. 113: 2813-2819.

Liu, X., Robinson, G.W., Wagner, K.U., Garrett, L., Wynshaw-Boris, A., and Hennighausen, L. 1997. Stat5a is mandatory for adult mammary gland development and lactogenesis. Genes \& Dev. 11: 179-186.

Marine, J.C., Topham, D.J., McKay, C., Wang, D., Parganas, E., Stravopodis, D., Yoshimura, A., and Ihle, J.N. 1999a. SOCS1 deficiency causes a lymphocyte-dependent perinatal lethality. Cell 98: 609-616.

Marine, J.C., McKay, C., Wang, D., Topham, D.J., Parganas, E., Nakajima, H., Pendeville, H., Yasukawa, H., Sasaki, A., Yoshimura, A., and Ihle, J.N. 1999b. SOCS3 is essential in the regulation of fetal liver erythropoiesis. Cell 98: 617-627.

Matsumoto, A., Seki, Y., Kubo, M., Ohtsuka, S., Suzuki, A., Hayashi, I., Tsuji, K., Nakahata, T., Okabe, M., Yamada, S., et al. 1999. Suppression of STAT5 functions in liver, mammary glands, and T cells in cytokine-inducible SH2-containing protein 1 transgenic mice. Mol. Cell. Biol. 19: 6396-6407.

Metcalf, D., Greenhalgh, C.J., Viney, E., Willson, T.A., Starr, R., Nicola, N.A., Hilton, D.J., and Alexander, W.S. 2000. Gigantism in mice lacking suppressor of cytokine signalling-2. Nature 405: 1069-1073.

Naka, T., Narazaki, M., Hirata, M., Matsumoto, T., Minamoto, S., Aono, A., Nishimoto, N., Kajita, T., Taga, T., Yoshizaki, K., et al. 1997. Structure and function of a new STAT-induced STAT inhibitor. $\mathrm{Na}$ ture 387: 924-929.

Naka, T., Matsumoto, T., Narazaki, M., Fujimoto, M., Morita, Y., Ohsawa, Y., Saito, H., Nagasawa, T., Uchiyama, Y., and Kishimoto, T. 1998. Accelerated apoptosis of lymphocytes by augmented induction of Bax in SSI-1 (STAT-induced STAT inhibitor-1) deficient mice. Proc. Natl. Acad. Sci. 95: 15577-15582.

Ormandy, C.J., Camus, A., Barra, J., Damotte, D., Lucas, B., Buteau, H., Edery, M., Brousse, N., Babinet, C., Binart, N., and Kelly, P.A. 1997. Null mutation of the prolactin receptor gene produces multiple reproductive defects in the mouse. Genes \& Dev. 11: 167-178.

Pezet, A., Favre, H., Kelly, P.A., and Edery, M. 1999. Inhibition and restoration of prolactin signal transduction by suppressors of cytokine signaling. J. Biol. Chem. 274: 24497-24502.

Starr, R., Willson, T.A., Viney, E.M., Murray, L.J., Rayner, J.R., Jenkins, B.J., Gonda, T.J., Alexander, W.S., Metcalf, D., Nicola, N.A., et al. 1997. A family of cytokine-inducible inhibitors of signalling. Nature 387: 917-921.

Starr, R., Metcalf, D., Elefanty, A.G., Brysha, M., Willson, T.A., Nicola, N.A., Hilton, D.J., and Alexander, W.S. 1998. Liver degeneration and lymphoid deficiencies in mice lacking suppressor of cytokine signaling-1. Proc. Nat1. Acad. Sci. 95: 14395-14399.

Teglund, S., McKay, C., Schuetz, E., van Deursen, J.M., Stravopodis, D., Wang, D., Brown, M., Bodner, S., Grosveld, G., and Ihle, J.N. 1998 Stat5a and Stat5b proteins have essential and nonessential, or redundant, roles in cytokine responses. Cell 93: 841-850.

Tomic, S., Chughtai, N., and Ali, S. 1999. SOCS-1, -2, -3: Selective targets and functions downstream of the prolactin receptor. Mol. Cell. Endocrinol. 158: 45-54.

Vonderhaar, B.K. 1987. Prolactin: Transport, function, and receptors in mammary gland development and differentiation. In The mammary gland (ed. M.C. Neville and C.W. Daniel), pp. 383-438. Plenum Press, NY.

Watson, C.J. and Burdon, T.G. 1996. Prolactin signal transduction mechanisms in the mammary gland: The role of the Jak/Stat pathway. Rev. Reprod. 1: 1-5.

Weiss, M.J., Keller, G., and Orkin, S.H. 1994. Novel insights into erythroid development revealed through in vitro differentiation of GATA-1 embryonic stem cells. Genes \& Dev. 8: 1184-1197.

Wilde, C.J. and Hurley, W.L. 1996. Animal models for the study of milk secretion. J. Mammary Gland Biol. Neoplasia 1: 123-134.

Wilkinson, D. 1992. In situ hybridisation. IRL, NY.

Yasukawa, H., Misawa, H., Sakamoto, H., Masuhara, M., Sasaki, A., Wakioka, T., Ohtsuka, S., Imaizumi, T., Matsuda, T., Ihle, J.N., et al. 1999. The JAK-binding protein JAB inhibits Janus tyrosine kinase activity through binding in the activation loop. EMBO J. 18: 1309-1320.

Yoshimura, A. 1998. The CIS/JAB family: Novel negative regulators of JAK signaling pathways. Leukemia 12: 1851-1857. 


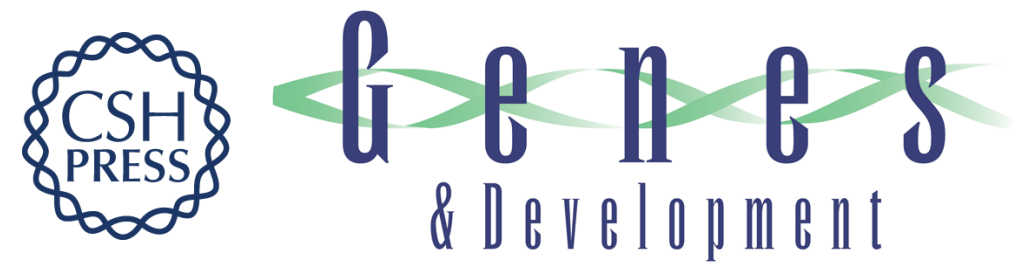

\section{SOCS1 deficiency results in accelerated mammary gland development and rescues lactation in prolactin receptor-deficient mice}

Geoffrey J. Lindeman, Sergio Wittlin, Hania Lada, et al.

Genes Dev. 2001, 15:

Access the most recent version at doi:10.1101/gad.880801

References This article cites 29 articles, 13 of which can be accessed free at: http://genesdev.cshlp.org/content/15/13/1631.full.html\#ref-list-1

License

Email Alerting Service

Receive free email alerts when new articles cite this article - sign up in the box at the top right corner of the article or click here.

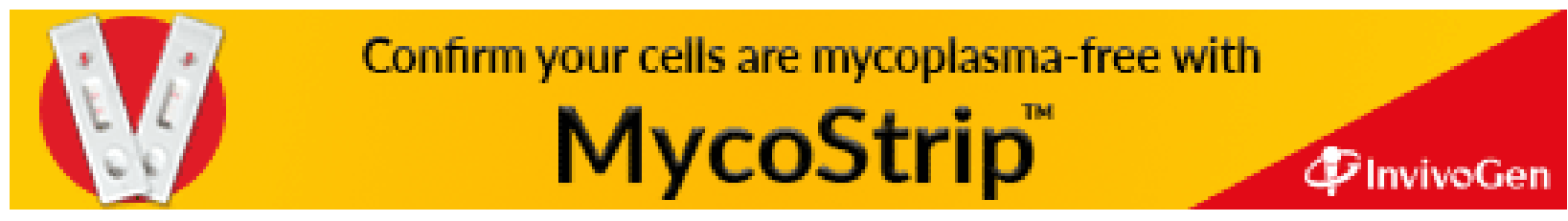

